\title{
ESSAY
}

\section{THE PROBLEM OF PROCESS IN BIOTECHNOLOGY}

Dan L. Burk*

TABLE OF CONTENTS

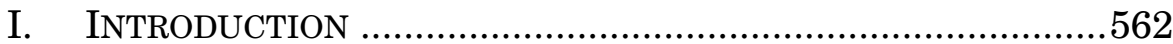

II. PROCESS PATENT PARAdOXES ..............................................563

III. OFFSHORE PROCESSES.......................................................566

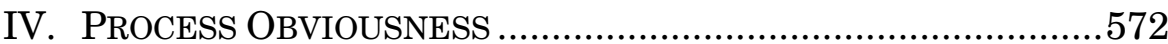

A. The Durden Problem ...................................................572

B. Macromolecular Structure .........................................575

V. Process Utility...............................................................5 578

VI. INFORMATION THEORY …...............................................582

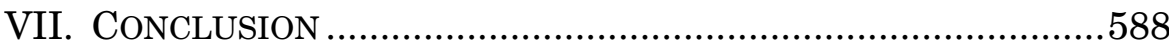

* Oppenheimer, Wolff \& Donnelly Professor of Law, University of Minnesota. This essay was originally presented as the 2005 Katz-Kiley Lecture at the University of Houston Law Center. I am grateful to Paul Janicke and his colleagues at the University of Houston for the opportunity to develop the themes discussed here and for the opportunity to have presented the twelfth in the series of distinguished lectures. 
"Sometimes it's damned hard to tell the dancer from the dance."

\section{INTRODUCTION}

Almost from its inception, modern biotechnology, founded on the tools of molecular genetics, posed a knotty problem for the patent system. Were living organisms within the statutory subject matter of patent law? How could biotechnology be differentiated from products of nature? Were recombinant proteins patentable in light of their natural counterparts? Did the translational relationship between nucleic acids and proteins render gene sequences of known proteins obvious? Could a written patent enable the use of unique biological materials?

Over the past three decades, courts in the United States have answered such questions, to a greater or lesser degree of satisfaction. Controversy remains as to whether the answers are satisfactory, or whether they are the best answers, but they are answers of some sort. At the same time, however, the opinions intended to resolve these patent questions are often themselves a bit unsettling, in many instances raising new and more difficult subsidiary questions. I will focus here on one of these issues, which becomes apparent only when viewing an emergent pattern from the larger pool of biotechnology cases. This issue arises from the distinction in patent law between process and product. Patent law routinely relies on distinctions between products and processes, but the courts appear to have a great deal of trouble distinguishing the two when it comes to biotechnology cases.

On careful examination, these anomalies appear to be variations on a recurring process-related theme that is characteristic of biotechnology patenting. Additionally, one quickly gets the sense from these cases that something more profound than a bit of judicial confusion is responsible for the problem; something else seems to be bubbling to the surface where biotechnology patents are at issue. In this Essay I will suggest that it is no accident that biotechnology patent cases repeatedly coalesce around difficult process-related issues, and that biotechnology patenting is where a discontinuity at the center of patent law has finally come to light.

1. Roger Zelazny, The Courts of Chaos 74 (1978); see also William Butler Yeats, Among School Children, in The Collected Poems of W.B. Yeats 215, 217 (Richard J. Finneran ed., rev. 2d ed. 1996) ("How can we know the dancer from the dance?"). 
I will begin by reviewing a series of biotechnology cases that address different issues of patent law and which in one way or another implicate processes: either as the subject of the claims, or as bearing on the patentability of the claimed invention, or as bearing on the validity of the patent, or as bearing on the infringement of the claims. Although these cases run the doctrinal gamut from subject matter to utility to infringement, they share a common relational pattern of confounding the longstanding distinction between process and product. Where courts maintain the formal line between product and process the results are often nonsensical; where they blur the line, the results may be even worse.

After identifying and characterizing this common pattern, I offer some thoughts on its recurrent quality, and suggest that the nature of biotechnology will inevitably produce anomalies in the patent law's previous distinction between products and processes. This I suggest is due to the character of molecules as channels for informational transfer processes. I further argue that conflicts regarding process and product will be endemic not only to the patenting of biotechnology products, but also other informational products, particularly software. I conclude with some not entirely optimistic observations about the choices available in dealing with the problem of process in biotechnology and similar technologies.

\section{PRocess Patent Paradoxes}

Section 101 of the U.S. patent statute provides that patentable subject matter encompasses new and useful processes, machines, manufactures, and compositions, as well as improvements upon existing processes, machines, manufactures, and compositions. ${ }^{2}$ Since the landmark decision in Diamond $v$. Chakrabarty, the Supreme Court has declared that these categories are illustrative, intended to suggest the kinds of subject matter contemplated by the Patent Act. ${ }^{3}$ The ultimate intent of the statute is to encompass "anything under the sun" made by a human. ${ }^{4}$ But even without resort to the intent behind the articulated categories, it is difficult to imagine an invention that cannot, with a little imagination, fit into one or more of these categories. The scope of the category "composition of

2. $\quad 35$ U.S.C. $\S 101(2000)$.

3. See Diamond v. Chakrabarty, 447 U.S. 303, 308 (1980) (stating that Congress chose expansive terms such that "patent laws would be given wide scope"). (1952)).

4. Id. at 309 (quoting S. REP. No. 82-1979, at 5 (1952); H.R. REP. No. 82-1923, at 6 
matter" ${ }^{\prime 5}$ alone would seem to cover anything in the material world, including the other categories of machines and manufactures, and certainly the transgenic bacterium that was the subject of the Court's contemplation in Chakrabarty. ${ }^{6}$

But one category in the subject matter list does not seem to belong to the material world, and that is the category of processes. Processes operate on compositions of matter, including machines and article of manufacture, or their Einsteinian equivalent in energy, but processes are not themselves material. This distinction between the categories of patentable subject matter has led to a practical and rhetorical division. Whether contemplating patents in practice or in theory, attorneys and scholars typically divide the universe of patents into product patents, which encompass the categories of machines, compositions, and manufactures; and process patents, which cover the odd category out - that of new and useful processes.

Under the statute, a patent holder receives the exclusive rights to make, use, sell, offer for sale, and import the claimed invention. ${ }^{7}$ Drawing upon this terminology of the exclusive rights, the category of process patents is frequently subdivided into the categories of "method of making" patents and "method of using" patents. These designations indicate processes that either employ a certain input or that result in a certain end product. Where such method patents are concerned, the exclusive rights conferred under the statute are effectively coterminous with the nature of the invention: it is by definition infringement to use a patented method of use without authorization. ${ }^{8}$

But in the case of product patents, the range of exclusive rights under the statute encompasses the related methods of making the product or methods of using the product. Because the statute confers upon the patent holder the exclusive right to make the claimed invention and to use the claimed invention, ${ }^{9}$ all methods of making and methods of use are caught up in the scope of a product patent, even if the patent discloses only a single use for the product. Thus "new uses" of a product are

5. 35 U.S.C. $\S 101$.

6. However, the Canadian Supreme Court, interpreting identical language in the Canadian patent statute, held that a transgenic mouse, being a living creature, was not a composition of matter. See Harvard Coll. v. Canada (Commissioner of Patents), [2002] 4 S.C.R. 45. One is left to wonder what else the mouse could possibly be composed from. See Dan L. Burk, Reflections in a Darkling Glass: A Comparative Contemplation of the Harvard College Decision, 39 CANADIAN BUS. L.J. 219, 221 (2003).

7. 35 U.S.C. $\$ 271(\mathrm{a})$.

8. Id.

9. Id. 
already encompassed in a patent on the product, even if they are novel and nonobvious and entitled to their own process patent. When the new use is invented by someone other than the holder of a dominant product patent, a subordinate patent on the new use may create a situation of blocking patents.

This perhaps surprising relationship between the employment of an invention and the rights conferred under the statute is not confined to the interaction of the subject matter and exclusive rights provisions of the Patent Act. Rather, it runs throughout the statute. Together with Professor Mark Lemley, I have elsewhere explored how the terminology of "making" and "using" repeats itself in a variety of provisions scattered across the statute, underpinning an array of related inherency doctrines in the law of novelty, disclosure, infringement, and statutory bar. ${ }^{10}$ In addition, where this language is applied to process-based inventions, it generates a set of doctrinal problems that has long been apparent in the chemical arts, because so many chemical inventions are process-based. These problems have been even more prominent in biotechnology, almost from the advent of its commercial application.

The practical differences between product and process patents also routinely present vexing operational problems in terms of policing and enforcing the patent. Innovators have long preferred product protection to process protection due to such impediments. It is relatively simple to detect the unauthorized sale or presence of a patented product in the marketplace or to interdict such a product at the border. It is far more difficult to determine whether a particular product has been produced by the unauthorized practice of a patented process, or whether a patented process is otherwise in hidden use in a manufacturing facility.

Such problems of detection and enforcement are greatly exacerbated by the territorial nature of patent law. As a matter of jurisdiction, international comity, and respect for the national sovereignty of other states, U.S. patent law ends at the border of the United States, its territories and possessions. ${ }^{11}$ It might therefore be feasible to evade the prohibitions of a process patent by practicing the process outside the United States, where the U.S. patent would not reach, and shipping a resulting product into U.S. territory. Under such a scheme, so long as the product is unpatented, no U.S. patent would have been infringed. And it

10. See Dan L. Burk \& Mark A. Lemley, Inherency, 47 WM. \& MARY L. REV. 371 (2005).

11. Deepsouth Packing Co. v. Laitram Corp., 406 U.S. 518, 531 (1972). 
was just such a scenario that prompted the earliest manifestations of the problem of process in biotechnology.

\section{OFFSHORE PROCESSES}

Recognizing the possibility of offshore process patent evasion, Congress amended the patent statute in 1988 to make the importation of a product produced outside of U.S. territory by means of a process that is the subject of a U.S. patent an act of infringement. ${ }^{12}$ Because of the territorial restriction of patent law, the activity must have some nexus with U.S. territory in order to trigger such infringement provisions. ${ }^{13}$ For the Process Patent Amendments Act of 1988, this trigger is the passage of the end product into U.S. territory. ${ }^{14}$ But the problem of detection remains: how to determine whether a given product coming from outside the United States was produced by the patented process. Some products might have been produced by a variety of processes, some patented and some unpatented. Consequently, the 1988 statutory amendments include an elaborate set of evidentiary provisions, including a provision that shifts to an alleged infringer the burden of proving that the patented process was not used, once a patent holder has made an unsuccessful good faith effort to determine such facts. ${ }^{15}$

Biotechnology was clearly one of the primary considerations for Congressional concern while enacting these amendments. Since many of the early biotechnology ventures were directed toward putting new recombinant DNA processes to work producing pharmaceutically active proteins that were old in the art, biotechnology presented exactly the process patent profile for which the 1988 amendments were intended. ${ }^{16}$ Yet the first biotechnology case to invoke $\S 271(\mathrm{~g})$ was judged to fall outside the terms of the statute. Amgen, Inc. v. U.S. International Trade Commission involved novel recombinant genetic production of erythtropoietin (EPO), a pharmaceutical protein used to stimulate red blood cell production. $^{17}$ EPO itself was unpatentable, having been long before characterized from human blood extracts, but recombinant DNA techniques had allowed the

12. $\$ 271(\mathrm{~g})$ (originally enacted as the Process Patent Amendments Act of 1988, Pub. L. No. 100-418, § 9003, 102 Stat. 1107, 1563-64).

13. Deepsouth Packing, 406 U.S. at 527.

14. $\S 271(\mathrm{~g})$.

15. Id. $\S 295$ (originally enacted as the Process Patent Amendments Act of 1988, Pub. L. No. 100-418, § 9005, 102 Stat. 1107, 1566).

16. S. REP. NO. 100-83, at 51 (1987).

17. Amgen, Inc. v. U.S. Int'l Trade Comm'n, 902 F.2d 1532, 1533 (Fed. Cir. 1990). 
creation of a patented, genetically engineered cell lines that would secrete the protein. ${ }^{18}$ The American patent holder, Amgen, sought an order from the International Trade Commission (ITC) under the Process Patent Amendments Act enjoining importation of an EPO product produced by the Japanese firm Chugai. ${ }^{19}$ Amgen alleged that, in Japan, beyond the territorial reach of the Amgen patent, Chugai was producing the EPO using cells which were covered by the patent. ${ }^{20}$

On appeal from a decision of the ITC dismissing Amgen's complaint for lack of subject matter jurisdiction, the Federal Circuit held the complaint to have been properly dismissed, but on the merits, not for lack of jurisdiction. ${ }^{21}$ The ITC had reasoned that the relevant statute was drawn to importation of products produced outside the United States by means of a process patented in the United States, but Chugai's EPO was produced outside the United States using a product-transgenic cells - that was patented in the United States. ${ }^{22}$ Consequently, the statute did not apply. ${ }^{23}$ Amgen in turn asserted that its patent was directed to "non-traditional" or "unconventional" process claims - that is, to patented cells within which processes were occurring. ${ }^{24}$ The court rejected this assertion, reasoning that the cell line patent did not cover the cells' processes any more than a patent on a machine would cover the processes occurring within the machine. ${ }^{25}$

On its face, this seems the right result. In rejecting the claim that the cells are "non-traditional" processes, the opinion simply toes the well-worn line between product patents and process patents. "Non-traditional" processes seem not to be processes, but rather seem to be a sort of newspeak euphemism for products. Cells are material items - things - products - and not processes. The statute is drawn to process patents, which means that it is not drawn to product patents. The two are distinguishable and distinct. Congress meant to address the problem of nonmaterial processes offshore, not material products offshore.

\footnotetext{
18. Id.

19. Id. at 1534 .

20. Id. Amgen's claim in this case was not brought under 35 U.S.C. $\S 271(\mathrm{~g})$, but under a parallel trade provision from the same statutory enactment, 19 U.S.C. § 1337. Id.

21. Id. at 1540 .

22. In re Certain Recombinant Erythropoietin, 10 U.S.P.Q.2d 1906, 1911 (U.S. Int'l Trade Comm'n 1989).

23. Id.

24. Amgen, 902 F.2d at 1537.

25. Id. at $1537-38$.
} 
And yet, as material items go, cells are actually somewhat unusual. For one thing, they are alive, which is to say that they are dynamic, variable objects - they are products that "behave."26 This mercurial characteristic stems from their unusual composition; they are essentially bags of chemical processes. To be sure, there are plenty of material products floating around in the bags, interacting with one another to effectuate the processes that make up cellular metabolism. But in a very real sense cells are characterized as much by their processes as by their material make-up. It is not at all beyond the pale to think of the cell as a system, or set of systems, rather than as a collection of molecules - to think of them as the sum of their processes. Which is to say, it is quite possible to think of them, perhaps nontraditionally, as processes in progress.

Other machines, materials, and manufactures are to some extent also the sum of their processes - their attributes include undergoing aging, expansion, compression, evaporation, and so on. But the chemical activity of a living organism is at least different in scope, and perhaps different in kind from that of any other patentable subject matter. The chemical activity inherent in living organisms will, as a rule, be far more varied and dynamic than anything found in other, inanimate patentable subject matter. Patentable living organisms are also generally valued precisely because of their internal process activity, which in turn typically constitutes the patentable point of novelty for the organism. Even in the rare case, such as zeolites, in which a nonliving patentable material is arguably valued for its reactive qualities, it is only a single, static quality that is found in such materials. $^{27}$

This view of cells - a kind of product - as converging on processes was a harbinger of things to come. The Federal Circuit revisited the distinction between offshore products and offshore processes in a later case, Bio-Technology General Corp. $v$. Genentech, Inc., involving importation of recombinant human growth hormone, or hGH. ${ }^{28}$ Much like EPO, this biologically active protein which governs human growth and development, had long before been characterized by classic biochemistry, and so the protein itself could not be patented. Instead, the genetic

26. Cf. Pamela Samuelson et al., A Manifesto Concerning the Legal Protection of Computer Programs, 94 CoLUM. L. REV. 2308 (1994) (grounding copyright analysis of software in a characterization of computer programs as texts that "behave").

27. A zeolite is an aluminosilicate lattice with an open porous structure, useful for hosting catalytic reactions or cation exchange. See P.W. ATKINS, GENERAL CHEMISTRY 735 (1989).

28. Bio-Tech. Gen. Corp. v. Genentech, Inc., 80 F.3d 1553, 1556 (Fed. Cir. 1996). 
molecules used to code for the protein, and the processes associated with those molecules, were patented. ${ }^{29}$ Genentech held patents which covered, inter alia, a process for preparing a recombinant DNA plasmid that could be used to transform cells that would then produce $\mathrm{hGH}^{30}$ An Israeli company, BioTechnology General, had used the patented Genentech process to produce plasmids, and to transform cells that produced hGH which was imported into the United States. ${ }^{31}$ Genentech sued under 35 U.S.C. $§ 271(\mathrm{~g})$, arguing that Bio-Technology had used a patented process offshore to produce a product that was brought into the United States, triggering liability. ${ }^{32}$

Bio-Technology in turn argued that $\S 271(\mathrm{~g})$ was inapplicable on the same grounds as those adopted by the court in Amgen $v$. ITC: that what was used offshore to make the protein was a product-a DNA molecule - not a process. $^{33}$ The process that Genentech claimed in its patent was used to make a plasmid. ${ }^{34}$ The product of the patented process, the plasmid, was not brought into the United States, but was used offshore to produce an unpatentable protein (hGH) that was instead brought into the United States. ${ }^{35}$ Thus any process implicated under $\S 271(\mathrm{~g})$ was twice removed from the product that reached American soil. Consequently, Bio-Technology asserted that under the statute the hGH was not "made by" the patented plasmid construction process; the plasmid was made by the patented process, and the hGH was "made by" a different process employing the plasmid. ${ }^{36}$

This argument might seem relatively straightforward, especially in light of the Amgen decision. But the court disagreed with this line of reasoning, deciding that the hGH was "made by" the plasmid construction process. "Made" or "making" could only be found in the most attenuated sense; the direct output of the patented product was an input into the process that produced the imported product. And significantly, such making was purely informational: only information was transferred from one process to the next, and ultimately to the end product. ${ }^{38}$ Because it was

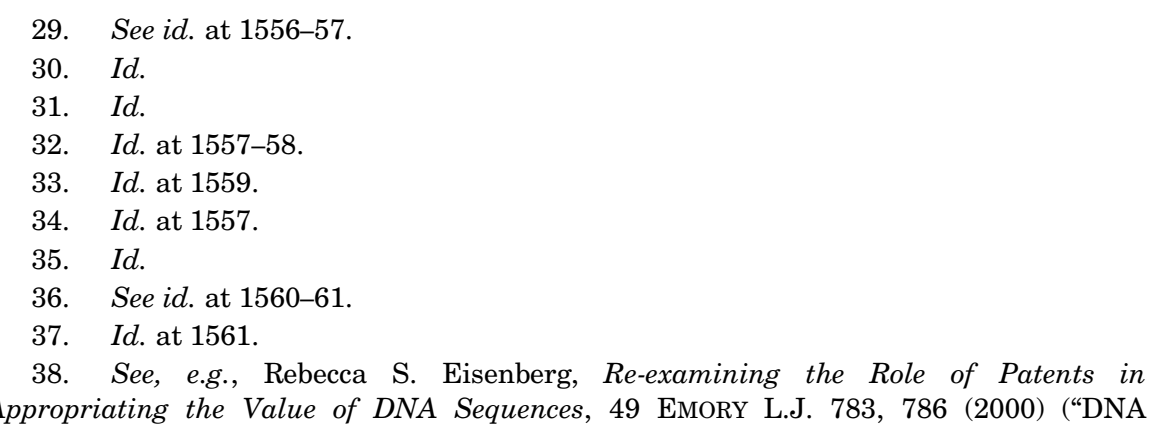


the genetic template that was made by the patented process, no transfer or incorporation of physical material into the final product occurred, as might occur with chemical precursors.

The implications of this decision became apparent in a more recent case, Bayer $v$. Housey, in which the Federal Circuit considered the scope of $\S 271(\mathrm{~g})$ in the context of transborder movement of purely informational "products." ${ }^{39}$ In Bayer, the defendant in a declaratory judgment action owned a series of patents directed to methods for screening cell lines to determine the effects of putative protein activators or inhibitors; the response of the cells to test substances would identify the activating or inhibiting effects of the substance. ${ }^{40}$ Defendants alleged that the plaintiff had violated $\S 271(\mathrm{~g})$ by employing the screening method overseas, then using the information gained from the method to develop and sell pharmaceutical compositions in the United States. ${ }^{41}$

The District Court dismissed the $\S 271(\mathrm{~g})$ claims, reasoning that the statute was drawn to the products of methods of manufacture, not to information gathered by assessment methods. ${ }^{42}$ The Federal Circuit upheld the ruling, on the theory that the term "made" in the statute meant "manufactured," that manufacture entails production of tangible products, and that intangible items such as information are by definition not manufactured. ${ }^{43}$ The court distinguished the result in BioTechnology by reasoning that in the case at bar, the information regarding protein activation or inhibition was not used in the physical synthesis of a pharmaceutical product, whereas the plasmid in Bio-Technology was physically involved in the synthesis of the protein product. ${ }^{44}$

As a reductio ad absurdum of the plaintiff's argument, the court further observed that if information were included in the universe of imported products covered under $\S 271(\mathrm{~g})$, infringement could hypothetically be triggered by someone entering the United States with knowledge gleaned from a patented process, thereby illegally "importing" information into the United States in his brain. ${ }^{45}$ It is unclear from this dicta

\footnotetext{
sequences are not simply molecules, they are also information.").

39. Bayer AG v. Housey Pharms., Inc., 340 F.3d 1367 (Fed. Cir. 2003).

40. Id. at $1368-69$

41. Id. at 1369-70.

42. Id. at 1370 .

43. Id. at 1376-77.

44. Id. at 1377 .

45. See id. at 1376 (recognizing that such a situation would be "illogical" and could not have been intended).
} 
whether the court appreciated that its observation regarding "patented thoughts" implicates the "mental steps" doctrine. ${ }^{46}$ Patent law long ago developed a presumption against process patents with claims drawn to "mental steps," in part because such claims seemed to be indefinite or to lack enablement; inventions that occurred in whole or in part within the human mind seemed sufficiently indeterminate that they would frustrate practical implementation. ${ }^{47}$ Such patents also raised policy issues regarding the intersection of patent law and the First Amendment. ${ }^{48}$ On the basis of this doctrine, courts and the Patent Office were initially concerned about the propriety of patenting computer software because sufficiently broad software claims might sweep in processes occurring in the human mind. ${ }^{49}$

But the "mental steps" doctrine has largely fallen into desuetude, in part due to Supreme Court precedent that limited algorithmic patents on such processes to those embedded in tangible embodiments. ${ }^{50}$ Ironically, it was the Federal Circuit that discarded the tangibility requirement, holding that in the context of "business methods," a numerical output, so long as it was useful, is sufficiently tangible and concrete to satisfy the requirements for patentable subject matter. ${ }^{51}$ Thus, the Federal Circuit's concern that screening information was not sufficiently tangible to trigger importation liability seems odd, particularly since the Federal Circuit has recently held that the export of information on magnetic media is sufficient to trigger liability under another statutory provision related to offshore manufacturing. ${ }^{52}$ Presumably the screening information came

46. See Dan L. Burk, Patenting Speech, 79 TEx. L. Rev. 99, 137-38 (2000) (discussing generally the "mental steps" doctrine).

47. See id. at 139-40.

48. See id. at 140.

49. Pamela Samuelson, Benson Revisited: The Case Against Patent Protection for Algorithms and Other Computer Program-Related Inventions, 39 EMORY L.J. 1025, 104344 (1990).

50. See Diamond v. Diehr, 450 U.S. 175, 192 (1981) (concluding that a process which uses a mathematical formula to "transform[ ] or reduc[e] an article to a different state or thing" meets the requirements of § 101); Burk, supra note 46, at 138 ("Almost as soon as [the mental steps doctrine] was formulated, however, [it] began to erode.”).

51. See AT\&T Corp. v. Excel Commc'ns, Inc., 172 F.3d 1352, 1358 (Fed. Cir. 1999); State St. Bank \& Trust Co. v. Signature Fin. Group, Inc., 149 F.3d 1368, 1373 (Fed. Cir. 1998).

52. See Eolas Techs., Inc. v. Microsoft Corp., 399 F.3d 1325, 1339 (Fed. Cir. 2005). The statutory provision at issue in this case was 35 U.S.C. $§ 271(f)$, which essentially covers the inverse of $\S 271(\mathrm{~g})$; that is, it prohibits export of an unpatented product that will be incorporated into an infringing device or process outside the United States. See Bayer AG v. Housey Pharms., Inc., 340 F.3d 1367, 1374 (Fed. Cir. 2003) (discussing the conceptual and historical relationship between $\S 271(\mathrm{f})$ and $\S 271(\mathrm{~g})$ ). I have elsewhere explored some aspects of the relationship between these provisions and infringement of 
into the United States by means of some physical substratepaper or fiber-optic impulses or magnetic media, if not encoded in human neurons. The fact that information can be encoded in human neurons has not precluded its patentability when encoded in other forms. ${ }^{53}$

Equally troubling is the court's apparent extension of its reading of the term "made" to bifurcate informational "use" from "methods of making." Bayer argued that $\S 271(\mathrm{~g})$ was directed to methods of making, not methods of use, and that the Housey patents were use patents. ${ }^{54}$ The language of the opinion distinguishing the Bio-Technology decision speaks to this distinction-implying, if not stating, that an end product is not "made by" methods of "gathering information," while construction of a plasmid is a method of making an eventual end product. ${ }^{55}$ This distinction is incredibly difficult to parse, as we have seen in each case that information was applied in a process, either embodied as DNA or as human know-how. This distinction may simply be another iteration of the court's insistence on tangible embodiment, but it seems to suggest that application of information cannot constitute a method of making a product, at least not for purposes of $\S 271(\mathrm{~g})$.

\section{PROCESS OBVIOUSNESS}

The ongoing difficulties regarding offshore biotechnology processes resonate to a surprising degree with the issues found in an ostensibly different area of patent law, that of obviousness. Biotechnology process obviousness questions have arisen in two different lines of cases, each dealing with the relationship between a known process and a novel product, but in markedly different situations.

\section{A. The Durden Problem}

One of the earliest patent concerns of the biotechnology industry arose from a venerable series of not entirely consistent cases attempting to sort out the relationship between products and processes in the context of process renovation. ${ }^{56}$ Some of

process-based inventions. See Dan L. Burk, Patents in Cyberspace: Territoriality and Infringement on Global Computer Networks, 68 TUL. L. REV. 1, 34-36, 46 (1993).

53. See Burk, supra note 46, at 138-39 (observing that courts have held mechanically-implemented processes to be patentable even though the process could also be carried out by mental steps).

54. Bayer, 340 F.3d at 1370.

55. Id. at $1377-78$.

56. See Dan L. Burk, Biotechnology and Patent Law: Fitting Innovation to the 
these cases addressed the patentability of previously known processes where the starting material used in the process was known in the art, but the end products were novel and patentably nonobvious. ${ }^{57}$ Other cases dealt with the patentability of processes where the starting materials were novel, and sometimes patentably nonobvious, but the end product was known and fully expected from such a process. ${ }^{58}$ In general it seemed that the result in cases where the starting material was known in the art but the end product was patentable was that the process was deemed obvious and unpatentable; whereas, it appeared that in cases where the end product was known and obvious but the starting material was patentable that the process was deemed patentable as well.

The former type of cases often were grouped together as involving a "method of making" a patentable compound, whereas the latter type of cases became grouped together as involving a "method of using" a patentable compound, and attempts were made to distinguish the outcomes of the two sets of cases on that basis. ${ }^{59}$ Indeed, some of the later cases in the series explicitly articulated a distinction between renovated processes as methods of making versus renovated processes as methods of use, opining that only the latter methods acquired nonobviousness from their patentable starting materials. ${ }^{60}$ Patentable end products, these opinions suggested, might be made from old and obvious processes, but patentable starting materials imbued old processes with their nonobvious qualities.

These cases were viewed as presenting a particular problem for biotechnology due to the early reliance of the industry on process patent protection. ${ }^{61}$ Many of the pharmaceutical proteins that were produced early on in the industry were well known and previously characterized via classic biochemical analyses. Thus the products of the industry typically lacked novelty; instead, it was their production via recombinant DNA technology that was revolutionary. If the processes that produced the known products

Procrustean Bed, 17 RUTGers CoMPuTER \& TECH. L.J. 1, 33-34, 42-43 (1991).

57. See, e.g., In re Larsen, 292 F.2d 531, 532 (C.C.P.A. 1961).

58. See In re Mancy, 499 F.2d 1289, 1290 (C.C.P.A. 1974); In re Kuehl, 475 F.2d 658, 659 (C.C.P.A. 1973).

59. See Burk, supra note 56, at 43-50 (comparing the two varieties of cases).

60. See Mancy, 499 F.2d at 1292-93 ("In the method-of-use cases, ... the novelty of the starting material may lend unobviousness to the process."); Kuehl, 475 F.2d at 665 (disagreeing with the argument that "the claims calling for a process using an unobvious composition ought to be treated identically with claims calling for the process of making an unobvious composition").

61. See Burk, supra note 56, at 52-53; see also In re Durden, 763 F.2d 1406 (Fed. Cir 1985) 
were themselves unpatentable for obviousness, then the industry was left with little patent protection. In fact, the erythropoietin that was the subject of the Amgen dispute before the ITC was precisely in this position: the protein itself lacked novelty, and a claim to the process had been rejected under the Durden holding, leaving Amgen with only its cell line patents to rely on. ${ }^{62}$

At times the cases appear to intermix novelty and nonobviousness, and this intermixture is perhaps a source of the confusion in the cases. But it is perhaps an understandable confusion, as much of the value of the cases is to display that, although novelty and nonobviousness are ostensibly separate issues, they are intertwined. The cases repeatedly focus on the question of whether in an obviousness analysis a court or the Patent Office was effectively treating a novel product as if it were prior art. ${ }^{63}$ In other words, given the existence of a particular product, one of ordinary skill might be motivated to prepare it via a particular process, or to use it in a particular process to produce some end product-but the question remained whether, for purposes of patenting either type of renovated process, the novel product should be taken as given.

The Federal Circuit attempted to clear up these issues in a series of cases beginning with the case that became eponymous with the process innovation question, In re Durden, which in some senses represented the convergence of the previous two lines of cases: both the starting materials and the end products in Durden were novel. ${ }^{64}$ The court then within a very short period took up the issue again with In re Pleuddemann and In re Ochiai. $^{65}$ The court attempted to bifurcate the novelty and obviousness questions by emphasizing that a known process may become novel when a novel starting material is employed, but it does not necessarily become nonobvious. ${ }^{66}$ And, while admitting that "generalized" language in previous cases could be read as adopting a per se rule regarding the obviousness of methods of making and methods of using, the court in Durden, Pleuddemann, and Ochiai insisted that each decision was unique to its own facts, and that no general rules could be drawn from the cases individually or from the line of cases as a whole. ${ }^{67}$

62. See Amgen, Inc. v. U.S. Int'l Trade Comm'n, 902 F.2d 1532, 1533-34 \& n.1 (Fed. Cir. 1990).

63. See, e.g., Kuehl, 475 F.2d at 662.

64. Durden, 763 F.2d at 1408.

65. In re Ochiai, 71 F.3d 1565 (Fed. Cir. 1995); In re Pleuddemann, 910 F.2d 823 (Fed. Cir. 1990).

66. Durden, 763 F.2d at 1410.

67. See Ochiai, 71 F.3d at 1569-72; Pleuddemann, 910 F.2d at 826-27; Durden at 
In so doing, the court effectively labeled previous language regarding "methods of making" and "methods of using" as dicta. At the same time, despite the court's repeated insistence that the obviousness of a renovated process can only be evaluated on a case-by-case basis, the analysis adopted in the Durden line of cases suggests that certain outcomes are, if not predetermined, at least logically inevitable. For example, the court in In re Mancy reasoned that without possession of the novel starting material, it cannot be obvious to use the starting material in the process, for "one cannot choose from the unknown." ${ }^{68}$ As we will see, this logic was essentially adopted in later cases dealing with the obviousness of molecular structure, ${ }^{69}$ and articulates a logical relationship between the obviousness of a process and the novelty of its starting materials. Such a relationship may be inevitable when considering a process and its starting material, but is not necessarily an inevitable relationship between process and its output.

Similarly, in Pleuddemann, the Federal Circuit opined that a claim to a patentable compound and a claim to its use are two ways of looking at the same invention. ${ }^{70}$ This opinion recognizes the clear logical connection between product and process that, as we have noted, sounds in the exclusive rights granted to the patent owner. Such inventive identity between a product and the methods of using it suggests that the nonobviousness analysis in each case must yield the same result-yet the case denies any per se rule on the matter. The court's insistence that there were no per se rules eventually elicited more congenial examinations from the Patent Office, and the biotechnology industry successfully lobbied for statutory changes that guaranteed them nonobviousness for both product and associated process patents. ${ }^{71}$ But although these outcomes may have resolved the practical issues faced by the industry, the conceptual issues in the cases remained largely unresolved.

\section{B. Macromolecular Structure}

The problem of process obviousness re-appears in an inverted form in several more recent cases dealing with the patentability of DNA sequences. The leading opinions here are

\footnotetext{
1411.

68. In re Mancy, 499 F.2d 1289, 1293 (C.C.P.A. 1974).

69. See infra text accompanying notes 72-73.

70. Pleuddemann, 910 F.2d at 827.

71. See Pub. L. No. 104-41, § 1(3), 109 Stat. 351, 351 (1995) (codified at 35 U.S.C. $\S 103(b)(2000))$.
} 
the Federal Circuit decisions in In re Bell ${ }^{72}$ and In re Deuel. ${ }^{73}$ The facts of the two cases are remarkably similar; in each, the applicant had claimed a cDNA molecule coding for a protein known in the prior art. ${ }^{74}$ In the Bell case, the full amino acid sequence of the protein was known; in Deuel, a partial amino acid sequence was known. ${ }^{75}$ The prior art also disclosed methods for using the amino acid sequence information in developing probes that would identify the gene that would code for the protein. ${ }^{76}$ Such identification and isolation techniques were routine in the art, and typically successful in isolating a desired gene, although the methodology was sometimes labor intensive. ${ }^{77}$ Consequently, the Patent Office in each case rejected the claims as directed to an obvious invention - that is, drawn to the product of a routine and obvious process. The patent examiner in each case particularly stressed the known informational correspondence between DNA sequences and protein amino acid sequences. ${ }^{78}$

In both cases Judge Lourie, writing for the Federal Circuit panel, overruled the decision of a Patent Office, basing the holding on the formal distinction between product and process: according to the court, the rejection was improper because the claims were drawn to products, and not to the obvious processes by which those products were made. ${ }^{79}$ Although acknowledging the informational linkage between amino acid sequence and nucleotide sequence, the court resisted the Patent Office's attempts to trace the informational process backward, noting that redundancies in the genetic code's triplet codons ${ }^{80}$ create an inexact correspondence between a given protein and the nucleic acid that codes for the protein. Because millions of nucleic acids might be used as inputs to create a given protein, knowledge of the protein's amino acid sequence does not allow prediction of a particular nucleic acid sequence input. ${ }^{81}$ The court acknowledged

72. In re Bell, 991 F.2d 781 (Fed. Cir. 1993).

73. In re Deuel, 51 F.3d 1552 (Fed. Cir. 1995).

74. Id. at $1554 ;$ Bell, $991 \mathrm{~F} .2 \mathrm{~d}$ at $782-83$.

75. Deuel, 51 F.3d at 1560; Bell, 991 F.2d at 783.

76. Deuel, 51 F.3d at 1556.

77. See Bell, 991 F.2d at 783.

78. See Deuel, 51 F.3d at 1555-56; Bell, 991 F.2d at 783.

79. Deuel, 51 F.3d at 1559; Bell, 991 F.2d at 785.

80. Genetic base pairs are read in triplet "codons" to correspond to a particular amino acid. However, more than one set of triplet codons corresponds to a given amino acid, much as more than one letter corresponds to a given number on a telephone key pad. Cf. Dan L. Burk, Trademarks Along the Infobahn: A First Look at the Emerging Law of Cybermarks, 1 RICH. J.L. \& TECH. 1 II 57 (1995), http://law.richmond.edu/jolt/v1i1/ burk.html (discussing redundancy in alphanumeric telephone keypads).

81. See, e.g., Bell, 991 F.2d at 784. 
that a method for making a novel compound is critical to enabling that compound, but declined to say that the existence of an enabling process for making a product renders that product obvious. $^{82}$

At the very simplest level, these opinions seem to assert that a structural relationship between molecules, rather than an informational relationship, is necessary for obviousness. The court leaves open the possibility that a very direct informational relationship between end product and input might render the input obvious. ${ }^{83}$ But when coupled with the explicit rejection of the claim that a known, predictable process for producing a product does not render the product obvious, the court's decision seems to go much further. It appears to hold that only a structurally related prior art product, and not a prior art process, can render a product obvious-that is, at least for macromolecules, that the structure of a product is not suggested by a process. Even taking into account various caveats related to molecular biology's central dogma, it seems fair to generalize the holding to say that at a minimum, where a process of making a product does not allow prediction of the particular structure of the product, the process cannot render the product obvious.

Judge Lourie's reasoning in these cases has been criticized as a failure to understand the science involved, or at a minimum for a failure to respect the patent examiner's expertise. ${ }^{84}$ Given a known protein sequence and standardized laboratory procedures, making or isolating the corresponding DNA is, scientifically speaking, relatively trivial. But at the same time, the distinction Judge Lourie draws between product and process is doctrinally correct, if perhaps formalistic. A process for making a product and the product itself are two distinct inventions. The process for isolating or making the invention was well known and disclosed in the art, but the precise structure of the invention was not. The triviality or obviousness of a method of making a product is not dispositive evidence of the triviality or obviousness of the product made-indeed, unexpected or surprising results from a known method are a hallmark of nonobviousness. One might argue as to whether the inability to predict in advance the particular sequence of a DNA strand that will be isolated is really the same

82. Deuel, 51 F.3d at 1559.

83. See id.; Bell, 991 F.2d at 784.

84. See, e.g., Arti Rai, Addressing the Patent Gold Rush: The Role of Deference to PTO Patent Denials, 2 WASH. U. J.L. \& POL'Y 199, 218 n.64 (2000); Anita Varma \& David Abraham, DNA Is Different: Legal Obviousness and the Balance Between Biotech Inventors and the Market, 9 HARV. J.L. \& TECH. 53, 76-78 (1996). 
thing, for purposes of obviousness analysis, as isolating an unexpected or surprising DNA structure. But, analytically, the patentable qualities of a process and the product of the process should be quite distinct.

Nonetheless, the inference made by the Patent Office in these cases, that the product of a known and obvious process should itself be considered obvious, especially if the starting materials are known in the art, should by now be familiar. The issue in the cases may be viewed as a version of the Durden problem, essentially Durden in reverse. Rather than asking whether introducing a novel substrate into an obvious process makes a process nonobvious, Bell and Deuel ask whether using an obvious process to produce a novel product renders the product obvious. Product and process seem analytically distinct, and so the court reminds us in these opinions. But where biotechnology is concerned, the Federal Circuit is no more immune to blurring this distinction than is the Patent Office.

\section{PRocess Utility}

The pattern of conflating biotechnology process with biotechnology product is seen perhaps most recently in the Federal Circuit's opinion on patentable utility, In re Fisher. ${ }^{85}$ The Fisher decision concerned the "practical" utility of expressed sequence tags, or ESTs. ${ }^{86}$ ESTs are short complimentary DNA (cDNA) transcripts, reverse transcribed from messenger RNAs (mRNA); they can be rapidly generated from the population of mRNAs in a cell, and since the mRNAs are transcribed from active genomic DNA cistrons, their ESTs constitute partial sequences of all or most of the active genes in a cell. ${ }^{87}$ The patentability of these partial sequences had been controversial since the technology for rapidly generating them was developed in part because such patents would partially cover genes of unknown function. ${ }^{88}$ The ESTs themselves have been alleged to have uses such as probes for gene identification, markers for chromosomal mapping, and primers for DNA replication via polymerase chain reaction (PCR) ${ }^{89}$ But such uses have been

85. In re Fisher, 421 F.3d 1365 (Fed. Cir. 2005).

86. Id. at $1367-68$.

87. See id. (outlining general characteristics of ESTs).

88. See Leslie Roberts, Genome Patent Fight Erupts, 254 ScI. 184, 184-85 (1991).

89. See Rebecca S. Eisenberg \& Robert P. Merges, Opinion Letter as to the Patentability of Certain Inventions Associated with the Identification of Partial cDNA Sequences, 23 AIPLA Q.J. 1, 13-14 (1995). 
criticized as mere pretense in order to file an early claim on the underlying gene.

Such uses were alleged in Fisher, but dismissed by the Federal Circuit as insubstantial, on the assumption that what was really at issue was a pre-emptive claim to the corresponding genes, and the functions of those genes was yet unknown. ${ }^{90}$ According to the opinion by Judge Michel, the ESTs lacked utility without a demonstration of the function of their underlying associated gene. ${ }^{91}$ As a matter of patent doctrine this conclusion is more than a bit odd; typically the standard for patentable utility is one of "bare utility" - only one plausible use need be identified, no matter how many other, possibly more valuable uses for the invention are later identified. ${ }^{92}$ Over a vigorous dissent by Judge Rader, the majority opinion acknowledged that the EST patent asserted a function for the molecules, but as Rader recognized, engaged in a value judgment regarding the utility of that function. ${ }^{93}$

In reaching this result, the court relied heavily on the earlier Supreme Court decision in Brenner $v$. Manson, holding that a process for producing a compound with no certain utility must itself lack utility, and so fail patentability. ${ }^{94}$ The problem in Brenner runs conceptually parallel to that in Durden and Deuel, contemplating whether some patentable quality of a product that is produced by a particular process suffuses the process by which it is made-in Durden, the qualities of interest were obviousness and novelty; in Deuel, it was obviousness; and in Brenner, utility. The Brenner court concluded that if an end product is useless, the associated process by which it is made must, logically, be useless as well. But this reasoning fails to maintain the conceptual separation of invention between product and process that was maintained in the other cases. The Brenner court famously opined that a patent is not a "hunting license"-that patents are granted on inventions with at least one known use, not in order to enable the search for a use. Yet it was not the claimed process that lacked a use; the process apparently worked flawlessly producing its intended output. ${ }^{95}$

\footnotetext{
90. Id. at 1374 .

91. Id. at $1365,1376$.

92. See Eric P. Mirabel, "Practical Utility" Is a Useless Concept, 36 AM. U. L. REv. 811, 813-14 (1987).

93. See Fisher, 421 F.3d at 1380 (Rader, J., dissenting).

94. Brenner v. Manson, 383 U.S. 519, 534-35 (1966).

95. Id. at 532 .
} 
The blurring of process utility and product utility in the Brenner analysis soon proliferated. Much as the decisions in BioTechnology and Durden would later impute the character of products to their associated processes and then to yet other associated products, lower courts soon extended the Brenner reasoning to products employed to produce novel but indeterminately useful products-somewhat ironically bringing the logic of the cases full circle, as the Brenner holding was itself an extension of product utility to a related process. In both In re Kirk $^{96}$ and In re Joly, ${ }^{97}$ the Federal Circuit's predecessor court declined to find utility for chemical intermediates-compounds that could be used in reactions to produce end products without known uses. ${ }^{98}$ Relying on Brenner, the Court of Customs and Patent Appeals held that proof a chemical would successfully function in a reaction was not enough to show utility without showing the utility of the end product. ${ }^{99}$ Judge Rich in dissent argued that chemical research tools were being held to an irrational standard, as it was inconceivable that the rationale in Brenner would be similarly applied to electrical or optical laboratory tools that had "no use" except to provide information for research purposes. ${ }^{100}$

Judge Rich's insight seems to apply with even greater force in the context of Fisher, given the prevalence of patentable, useful inventions that are intended to produce not merely an informational output but an actual chemical of unknown utility. It would seem odd indeed to claim a lack of utility for Sephadex columns or HPLC chromatographs, or other laboratory equipment intended to isolate and purify molecules of unknown function. A version of this consideration appears in Fisher in the comparison of ESTs to a microscope, as an example of a clearly patentable, useful tool for investigating specimens of unknown utility. ${ }^{101}$ But microscopes are tools of general applicability, and to the extent that the utility rationale in Fisher is not simply a façade for a policy judgment about the desirability of "upstream" patents early in the research process, much of the court's

\footnotetext{
96. In re Kirk, 376 F.2d 936 (C.C.P.A. 1967). The rejection in Kirk appeared to have more to do with indefinite disclosure than with utility, as the specification for the claimed compounds asserted somewhat tautologically that "one skilled in the art would know how to use the compounds . . . to take advantage of their presently-existing biological activity." $I d$. at 939 (internal quotation marks omitted).

97. In re Joly, 376 F.2d 906 (C.C.P.A. 1967).

98. Id. at $906-08$.

99. Kirk, 376 F.2d at 945-46; Joly, 376 F.2d at 908-09.

100. Kirk, 376 F.2d at 961 (Rich, J., dissenting).

101. In re Fisher, 421 F.3d 1365, 1373 (Fed. Cir. 2005).
} 
dissatisfaction with the claims seems to relate to the limited nature of the asserted uses. ${ }^{102}$ Far from lacking a "specific" utility, the utility claimed for the molecules in Fisher seems to be too specific - the asserted use as probes or markers related only to the particular coding sequence from which the ESTs were derived. ${ }^{103}$ The molecules could not, like a microscope or an HPLC column, be used for generalized investigative uses-hence the concern over a covert claim to the full gene sequences. ${ }^{104}$

Admittedly, the reasoning in this portion of the opinion is so baffling that it is nearly impossible to discern exactly what the court's rationale might be. The court differentiates genetic probes from microscopes on the basis that a microscope reveals the structure of a magnified specimen, whereas genetic probes do not reveal an entire structure. ${ }^{105}$ This rather dubious claim is of course not necessarily true of microscopes, and is decidedly untrue of the vast array of spectrophotometers, electrophoretic gels, high-pressure liquid chromatographs, scintillation counters, and other devices, indicators, and reagents that might be used to investigate biological molecules. Typically no one of these tools reveals the entire structure and function of the object under scientific investigation, but rather some specific characteristic of the molecule which is pieced together with evidence from a variety of tests and instruments, including nucleotide probes. One could hardly credit the argument that litmus paper lacks practical utility because it does not immediately reveal the structure and function of the substances it is used to test but only their acidity.

The Fisher decision can only be regarded as a failure to maintain the distinction that the Federal Circuit so scrupulously maintained in Bell and Deuel; in those cases the obviousness of the process did not determine the obviousness of the resulting compound. Similarly, in Pleudemann and in Ochiai the court insisted that the novelty of a product cannot dictate the novelty of an associated process, although one wonders how bright that delineation can be. At a minimum, such cases require us to ask why the utility - or lack of utility — of a product should dictate the utility of an associated process. But when considered alongside

102. Id. at 1369-76. The opinion eschews this rationale, claiming to base its outcome solely on statutory criteria, but only after citing Brenner $v$. Manson for the proposition that patents are "not a reward for the search, but compensation for its successful conclusion"-a clear policy rationale. Id. at 1376 (citing Brenner v. Manson, 383 U.S. 519, $535-36$ (1966)).

103. Id. at $1373-74$.

104. Id. at 1373 .

105. Id. 
the $\S 271(\mathrm{~g})$ process cases, we can begin to see why it is so difficult to keep biotechnology process considerations from spilling over to products, and vice-versa.

\section{INFORMATION THEORY}

The cases I have described here have not been previously considered as a set, but the deficiencies of individual cases have certainly been noticed. Particularly when considering cases such as Bell and Deuel, some commentators have argued that the application of patent law to biotechnology has gone awry because patents drawn to biological molecules are in fact drawn to genetic information, and so doctrines crafted for chemical discoveries are inapposite. ${ }^{106}$ The macromolecules that are covered in the claims of biotechnology patents, this argument goes, are not really what any patentee wants to control. Rather, it is the information encoded in the macromolecules-the genetic sequences-that patentees want to control, so that patenting the chemicals is a façade or an excuse for patenting sequence information. ${ }^{107}$ Small wonder that, when applied to biotechnology, doctrines drawn from traditional chemical patent cases fall short, if what is really at issue is the information, not the chemistry.

But this argument is not quite correct, nor, to the extent that it is correct, does is it fully comprehend the problem with biotechnology patents-either as a general matter or in the specific context of process patents. ${ }^{108}$ The argument that biotechnology patents are essentially drawn to information proves too much, in part because it plays fast and loose with the term "information." To the extent that the argument employs the term in a meaningful way, it might equally be said that all chemical patents-and indeed perhaps all patents-are in fact drawn to "information." And in the sense that this argument uses

106. See Rai, supra note 84, at 204; Arti K. Rai, Intellectual Property Rights in Biotechnology: Addressing New Technology, 34 WAKE FOREST L. REV. 827, 835-36 (1999); see also Rebecca Eisenberg, Molecules v. Information: Should Patents Protect Both?, 8 B.U. J. SCI. \& TECH. L. 190, 196-97 (2002).

107. See Varma \& Abraham, supra note 84, at 69.

108. I have certainly argued elsewhere that there is a good deal to be found wrong in the current configuration of biotechnology patenting but have suggested that such problems are due in some part to judicial misunderstanding of the biotechnology industry's structure and in large part to the judiciary's failure to tailor patent doctrine to accommodate that structure. See Dan L. Burk \& Mark A. Lemley, Is Patent Law Technology-Specific?, 17 BERKELEY TECH. L.J. 1155, 1155-56 (2002); Dan L. Burk \& Mark A. Lemley, Policy Levers in Patent Law, 89 VA. L. REv. 1575, 1577-78 (2003); see also Dan L. Burk, Biotechnology in the Federal Circuit: A Clockwork Lemon, 46 ARIZ. L. REV. 441, 441-42 (2004). 
the term "information," the embodiment claimed in a patent is always an excuse for controlling the underlying information.

This version of the "information patents" argument in part suffers from what has been called the "DNA mystique"; the trope that DNA constitutes a "master molecule" or "blueprint" for the living organism. ${ }^{109}$ The argument assumes that genetic information is hierarchically lodged in the DNA molecule. But one might equally plausibly argue for mRNA, ${ }^{110}$ or DNA polymerase,${ }^{111}$ or peptidyl transferase ${ }^{112}$ as the "master molecule" of the cell. Critical genetic information is lodged in the architecture of each of these molecules, as well as many others. Each molecule "knows" and "recognizes" the other molecules with which it interacts, effectively distributing information across a series of interconnected chemical pathways. Proper cellular functions are dependent on the joint and several functionality of such molecules.

DNA is of course a key component in the expression of genetic information, but it is not the only informational component and it does not exist in isolation. ${ }^{113}$ It rather functions within an interactive structural apparatus that as a whole forms an information transfer system. ${ }^{114}$ Rather than comparisons to blueprints and the like, DNA might better be compared to a cog in a machine, something like Babbage's famous "difference engine," the conceptual precursor to modern computing, which was intended to accomplish complicated numerical calculations by means of mechanical gears. ${ }^{115}$ DNA is an admittedly complex $\operatorname{cog}$ in a nanometer scale machine, but one that nonetheless physically interoperates with other structural mechanisms, and which is essentially inoperative outside its functional matrix. Due to its size, DNA can carry a very large amount of structural information, but this structural encoding is similarly the case for

109. See Dorothy Nelkin \& M. Susan lindee, The DNA Mystique: The Gene as a CULTURAL ICON 39, 41-42 (1995).

110. mRNA, or messenger RNA, is one type of polynucleotide transcript, complementary to DNA, which is involved in the assembly of proteins by ribosomes. See LUBERT STRYER, BIOCHEMISTRY 93-95 (3d ed. 1988).

111. DNA polymerase is a complex enzyme that replicates DNA by assembling nucleotide subunits into a polynucleotide chain complementary to an existing DNA molecule. See id. at 665-67.

112. Peptidyl transferase is the enzyme responsible for transferring amino acid subunits to ribosomes for linkage into polypeptide chains. See id. at 757.

113. See R.C. LeWontin, BIOlOGY AS IdEOLOGY: THE DoctRINE OF DNA 48 (1991).

114. Id.

115. See generally Doron Swade, The Difference Engine: Charles Babbage AND THE QUEST TO BUILD THE FIRST COMPUTER 1-6 (2000). 
all biological macromolecules and indeed is at some greater or lesser degree true of all chemical structures.

Adding some rigor to the use of the term "information" in the "information patents" argument would go far toward correcting the problems I have identified, but a rigorous reformulation of the argument would likely require elucidation of a theory of information flow well beyond the scope of this paper. ${ }^{116}$ For present purposes, it is sufficient to consider one widely employed measure of information transfer from communications theory and the physical sciences. This measure of information was famously articulated in the information "channel" equations developed by Claude Shannon, which ultimately define the transmission of information in terms of the uncertainty, or the entropy of a system. ${ }^{117}$ According to Shannon's theorems, all communications channels have some carrying capacity, or bandwidth. ${ }^{118}$ So long as a particular message remains within the carrying capacity of the channel, it can be transmitted losslessly by use of certain error-correction mechanisms. ${ }^{119}$ Additionally, the informative content of a message is directly related to the degree of uncertainty regarding its content. Predictable messages have a low information content; unexpected or surprising messages have a high information content. ${ }^{120}$ Resolution of uncertainty functions as a measure of information. ${ }^{121}$

Although Shannon was considering primarily electronic communications when he developed these theories, his work maps out a general theory of information and is not limited to electronic communications or for that matter to other human systems such as spoken or written communications. ${ }^{122}$ Since biological macromolecules carry a type of message, Shannon's theories yield important insights regarding the nature and

116. Under a comprehensive theory of information flow, not only biotechnological processes, but the structure of the universe generally may be viewed as composed of informational transfer processes. See LeE SMOLIn, THREe ROADS TO QUANTUM GRAVITY 55-56 (2001); see also Jacob D. Bekenstein, Information in the Holographic Universe, ScI. AM., Aug. 2003, at 58, 58.

117. Entropy in this context is not synonymous with thermodynamic entropy, although a relationship between the two concepts can be expressed. See JOHN R. PIERCE, AN InTRoduction to Information Theory: Symbols, Signals, \& Noise 24 (2d rev. ed. 1980). A very readable lay introduction to Shannon and subsequent information theory can be found in JEREMY CAMPBELl, GRAMMATICAL MAN: INFORMATION, ENTROPY, LANGUAGE, AND LIFE (1982).

118. CAMPBELL, supra note 117 , at 77-78.

119. Id.

120. See PIERCE, supra note 117, at 23.

121. See id.

122. Id. at 24 . 
functions of the code and of the channels carrying those messages. Shannon's work on information theory has been applied with considerable success to biological systems at the molecular level. Information theory has been used to define the information carrying capacity or bandwidth of macromolecules and their interactions in cellular processes. ${ }^{123}$ Information theory has also shown considerable explanatory power in illuminating the character and variety of error correction mechanisms that exist in cellular processes for transcription, translation, and replication. ${ }^{124}$

In terms of molecular biology, information is encoded in the architecture or structure of molecules. Information flow within a cell-or for that matter, between cells-occurs via the interaction of particular configurations of molecular structure with complementary configurations of molecular structure. ${ }^{125}$ Biological molecules interact and encode information not only via the spatial exclusions of their molecular form-which is to say, the spaces occupied by their repulsive electron shells-but also via the extended secondary, tertiary, and quaternary structures formed by the macromolecular chains, the clustered arrays of water molecules surrounding the macromolecules, the clouds of charged ions that macromolecules draw in their wake. These interlocking physical structures are the Shannonian "channels" by which information is conveyed from molecule to molecule. ${ }^{126}$

123. See, e.g., Armin O. Schmitt \& Hanspeter Herzel, Estimating the Entropy of DNA Sequences, 188 J. ThEORETICAL Biology 369, 369-70 (1997); Thomas D. Schneider, Information Content of Individual Genetic Sequences, 189 J. THEORETICAL Biology 427, 427-28 (1997); Bonnie J. Strait \& T. Gregory Dewey, The Shannon Information Entropy of Protein Sequences, 71 BIOPHYSICAL J. 148 (1996); Olaf Weiss et al., Information Content of Protein Sequences, 206 J. THEORETICAL BIOLOGY 379 (2000).

124. See, e.g., Sahotra Sarkar, Decoding "Coding"-Information and DNA, 46 BIOSCIENCE 857, 857 (1996); John Maynard Smith, The Concept of Information in Biology, 67 PHIL. ScI. 177, 177-78, (2000); Jack W. Szostak, Molecular Messages, 423 NATURE 689 (2003). See generally HUBERT P. YOCKEY, INFORMATION THEORY AND MOLECUlaR BIOLOGY 110-13 (1992). Unfortunately, information theories of molecular biology have recently been seized upon by proponents of "intelligent design" creationism to advance some dubious arguments against natural selection. See, e.g., William Dembski, Intelligent Design as a Theory of Information (Feb. 20, 1997) http://www.discovery.org/scripts/ viewDB/index.php?command=view\&id=118; see also Rich Baldwin, Information Theory and Creationism: William Dembski (June 14, 2005) http://www.talkorigins.org/faqs/ information/dembski.html (cataloging Dembski's substantive mistakes in the application of information theory to intelligent design).

125. Cf. John Collier, Causation Is the Transfer of Information, in CAUSATION AND LAWS OF NATURE 215, 221-23 (Howard Sankey ed., 1999).

126. Among legal commentators, Eisenberg has come perhaps closest to recognizing this characteristic of macromolecular inventions. See Eisenberg, supra note 106, at 196 (arguing that DNA is both a molecule and information). However, she appears to be addressing DNA sequence data as "information" for purposes of research, rather than as a mediator of entropic information. Id. at 198. 
Although this is not quite what Marshall McLuhan meant in his famous aphorism, in biotechnology the medium is quite literally the message. ${ }^{127}$

And it is here that the naïve version of the argument that biotechnology patents are information patents goes wrong; the argument assumes that the information is somehow separable from the molecule. The familiar "CATG" of DNA, which seems to display the information carried by the molecule, is merely a notational shorthand for a set of spatial configurations, as for that matter is the more extensive letter code for designating amino acid residues in a polypeptide chain. Such information is not by itself of interest, at least not the information represented in human-readable notation. However superficially appealing it may be to regard macromolecular information as the string of ATGCs or RGDSs in a database, it is the three-dimensional configuration of the molecule, as well as its associated physical structures, taken in the context of a complex molecular system, that encodes biological information.

As genomics shades into proteomics and beyond, ${ }^{128}$ molecular biologists are well aware that most of this extended molecular architecture is not reflected in their databases and may well be unpredictable based solely on a knowledge of primary macromolecular sequence. ${ }^{129}$ Primary sequence data is only a small part of the story, though over time ongoing research will doubtless flesh out other aspects of the story. But the point here is that primary sequence data, and for that matter even more elaborate molecular mapping, is at best only a human-readable shorthand for a particular spatial structure, and it is the spatial structure that acts to transfer information among the components of biological systems.

127. $C f$. Marshall Mcluhan, Understanding Media: The Extensions of Man 7 (1964) (stating famously that "the medium is the message").

128. The rapidly proliferating "omics" data collections now encompass everything from metabolomics, to glycomics to epigenomics. See Stephan Beck et al., From Genomics to Epigenomics: A Loftier View of Life, 17 NATURE BIOTECHNOLOGY 1144, 1144 (1999); Hui Ge et al., Integrating "Omic" Information: A Bridge Between Genomics and Systems Biology, 19 TREnds IN GEnetics 551, 551-58 (2003); Proteomics, Transcriptomics: What's in a Name?, 402 NATURE 715, 715 (1999) (showing the expansion of the "omic" suffix to other scientific fields).

129. Protein folding appears to be highly path-dependent; where as one might expect the amino acid chain to adopt the objectively lowest energy configuration, it may instead settle into an entropically low-energy state determined by the configurations available as the chain is formed. See Thomas E. Creighton, Understanding Protein Folding Pathways and Mechanisms, in PROTEIN Folding: DeCIPHERING THE SECOND HALF OF THE GENETIC CoDE 157, 158 (Lila M. Gierasch \& Jonathan King eds., 1990); Stryer, supra note 110, at $37-38$. 
This in some ways turns the argument from information patenting on its head; the problem is not that the information embedded in the molecule is valuable and the actual molecule is itself superfluous. Rather, since information is encoded as molecular structure, the information is only useful when embodied in such structures, which is to say that, ultimately, no one is really interested in strings of human-readable lettersthey are instead interested in what can be done with the structures such letters represent. And that in turn means that by necessity they must be interested in building physical informational structures-the molecules that are the conduit for information transfer.

These considerations of molecular architecture and information theory allow us to reformulate the information patenting argument to account for the recurrent peculiarities of biotechnology process patents. Correctly articulated, the argument should observe that it is the information flow that is of interest in biotechnology, and hence of interest in biotechnology patenting. The configuration of informational molecules is based upon the interaction with, and so upon the configuration of, precursor molecules. Because such molecular structure is the channel by which information is conveyed, the interaction of macromolecules is the point of interest in biotechnology patenting-and "interactions" should fall formally into the category of processes. But molecular structure defines the parameters for such a process, and structure falls formally into the category of products.

Consequently, in biotechnology, the structure of molecules and their interaction are essentially interconnected and largely inseparable except by the most extraordinary feat of formalistic categorization. When patent law attempts a formal categorization of biotechnology inventions into the usual binary schema, it typically fails, and confusion results. The novelty and value of biotechnological inventions lie in their processes, which are determined by their structures. If Marshall McLuhan had been a patent attorney, he might have observed that in biotechnology, the product is the process.

Biotechnology is probably not unique in this regard, and indeed a very rich formulation of information theory might suggest that the same analysis potentially applies to most, if not all, other patentable inventions. ${ }^{130}$ Just as Norbert Weiner

130. Indeed, viewing the world generally as constructed of informational objects, moral philosophers have begun constructing ethical systems on the tenets of information theory. See, e.g., Luciano Floridi, Information Ethics: Its Nature and Scope, 35 
famously argued that humans are persistent information patterns, ${ }^{131}$ the same might be said of other material structures, encompassing machines, compositions, manufactures, and anything else under the sun made by humans. This is precisely why the argument from information patenting proves too much: small molecules also convey information within their structure, interacting with other molecules to form composites with more entropically settled states. But while the separation of products and processes may well have been artificial for other technologies, the pretense becomes immanent in biotechnology and the effects inescapable. The result is a persistence of process issues in biotechnology cases and doctrinal confusion whenever they arise.

\section{CONCLUSION}

In a so-called information age, where inventions are increasingly likely to be informational in nature, biotechnology may not be unique as a technology in which the processional characteristics of products are likely to become apparent. For example, if the nascent nanotechnology industry develops along the trajectory expected-generating self-assembling structures-it may encounter similar patentability issues. This would hardly be surprising, given first that a good deal of nanotechnology to date has been at least inspired by, if not derived from, biological molecular structures; and given that, second, a good deal of nanotechnology innovation is directed to structures on a physical scale at which the informational nature of matter becomes paramount

Similarly, in discussing the informational nature of biotechnology, I have already made several references to software-patent law's other subject-matter problem child of the Twentieth and Twenty-first Centuries. Computer programs clearly constitute another information technology in which the

COMPUTERS \& SOC'Y 3, II 1.1-1.4 (2005) (defining and developing a code for information ethics); Luciano Floridi, Information Ethics: On the Philosophical Foundation of Computer Ethics, 1 ETHICS \& INFO. TECH. 37, 42-48 (1999) (advancing information ethics from the basis of computer ethics); Luciano Floridi \& J.W. Sanders, Entropy as Evil in Information Ethics, 1 ETICA E POLITICA 2, (1999), available at http://www.univ.trieste.it/ etica/1999_2/index.html. While these discussions have not explicitly addressed issues of information ownership, such a value system could have implications for the moral basis of the patent system. $C f$. Peter Drahos, A Philosophy of Intellectual Property (1996) (outlining moral bases for the provision of intellectual property).

131. See Norbert Weiner, The Human Use of Human Beings: Cybernetics AND SOCIETY 96 (2d ed. 1954). 
distinction between process and product poses a problem. The subject matter classification of software as a process or as something else was problematic almost from its earliest encounters with the patent system. ${ }^{132}$ But the informational nature of software has become a more serious difficulty as patent law disputes over software have begun to display an effect paralleling the breakdown of the fixation requirement in copyright-the alternative form of intellectual property protection for software. Copyright has long required as an incident of protection the creation of a material copy embodying the intangible protected work. ${ }^{133}$ Fixation in a tangible medium of expression functioned as a trigger point for intellectual property protection to attach and as a natural bottleneck at which the distribution of the work could be interdicted and controlled. But the increasing ease of digitizing copyrightable works has largely bypassed the requirement of fixation, ${ }^{134}$ as digitized works are only very lightly attached to any tangible medium. Indeed, courts have in many cases had to go through fairly contorted logic to find the fixation necessary for copyright to apply. ${ }^{135}$

In patent law, the tangibility doctrine articulated by the Supreme Court in the software decision of Diamond v. Diehr seemed to impose an effective fixation requirement upon patentable inventions. ${ }^{136}$ Software and other process inventions were patentable to the extent that they produced a concrete, tangible result, and it is worth noting that this result was conceptually quite tightly coupled to the patenting of biotechnology products announced in Diamond $v$. Chakrabarty. ${ }^{137}$ But as I indicated in discussing the transfer of information under $\S 271(\mathrm{~g})$ in Bayer $v$. Housey, the Federal Circuit has since taken "tangible" to be metaphorical rather

132. Samuelson, supra note 49, at 1041-47.

133. See 17 U.S.C. $\$ 101$ (2000 \& Supp. II 2004) (defining work and fixation).

134. See Dan L. Burk, Expression, Selection, Abstraction: Copyright's Golden Braid, 55 SYRACUSE L. REV. 593, 595-96 (2005).

135. Compare MAI Sys. Corp. v. Peak Computer, Inc., 991 F.2d 511, 517-18 (9th Cir. 1993) (holding that temporarily loading software into RAM constitutes fixation), and Midway Mfg. Co. v. Artic Int'l, Inc., 704 F.2d 1009, 1012 (7th Cir. 1983) (holding that video game output was sufficiently fixed in the circuits of a ROM chip), with NLFC, Inc. v. Devcom Mid-Am., Inc., 45 F.3d 231, 236 (7th Cir. 1995) (finding no fixation of software in a dedicated computer terminal).

136. See Diamond v. Diehr, 450 U.S. 175, 185-90 (1981).

137. For discussion of the historical and conceptual connections between these decisions, see Burk, supra note 6, at 222-25. 
than physical and equated it with "useful,"138 essentially decoupling process inventions from any physical substrate. ${ }^{139}$

This elimination of any tangibility requirement appears to leave software, even more than biotechnology, the subject of outright informational patenting, although the erosion of the product/process distinction in biotechnology cases indicates that regardless of material fixation, doctrinal anomalies are probably inevitable, as information products are lightly embodied anyway. I expect that there will be no easy solution to these anomalies so long as informational products remain within patentable subject matter. One might remove the product/process distinction, but that is simply getting rid of the canary so as not to detect the gasses in the mine. To remove informational products from patent law is probably to abandon the mine altogether. What may ultimately be necessary is an overhaul of patent law to recognize the informational nature of inventions that has become apparent in biotechnology, but which is only an instance of a larger phenomenon.

138. See AT\&T Corp. v. Excel Commc'ns, Inc., 172 F.3d 1352, 1358-59 (Fed. Cir. 1999); State St. Bank \& Trust Co. v. Signature Fin. Group, Inc., 149 F.3d 1368, 1373 (Fed. Cir. 1998).

139. See Rebecca Eisenberg, How Can You Patent Genes?, in Who Owns LIFE? 117, 120 (David Magnus et al. eds., 2002). 